\title{
Translating Animal Idioms from English into Arabic: An Application of Nida's Strategies for Translating Idioms
}

\section{Filwah Dawood Al-Qahtani}

Department of English Language and Literature

College of Languages and translation, Imam Mohammad Ibn Saud Islamic University (IMSIU)

Riyadh, Kingdom of Saudi Arabia

\section{Osama Abdulrhman Al Qahtani}

Department of English Language and Literature

College of Languages and translation, Imam Mohammad Ibn Saud Islamic University (IMSIU),

Riyadh, Kingdom of Saudi Arabia

Corresponding Author: osama.uni@ hotmail.com

Received: 7/24/2021

Accepted: 8/19/2021

Published: 8/25/2021

\begin{abstract}
Many animal-related idioms are found in Arabic and English languages. However, since there are some differences between Arab and western cultures in history, tradition, geographical environment and mode of thinking, animal idioms can create a cultural gap, which hinders mutual understanding between both cultures. The cultural gap is noticed when translating animal idioms from English into Arabic. Therefore, this research investigates problems encountering translators in the translation of animal idioms from English into Arabic. It also presents strategies that can be applied in the rendition of animal idioms from the source language into the target language. The study discusses problems and strategies of translating animal idioms based on Eugene Nida's strategies for translating idioms (1964). To conduct the study, the researcher developed an empirical survey adopting a mixed approach of qualitative and quantitative methods, to gain a detailed understanding of the translational problems and strategies followed by Saudi translators in the transference of animal idioms from English into Arabic. Findings of the study indicate that most translator respondents opted for the strategy of translating an idiom into a non-idiom even when a corresponding idiom is found in Arabic.
\end{abstract}

Keywords: animal idiom, English idioms, Nida's strategies, problems, translation

Cite as: Al-Qahtani, F. D., \& Al Qahtani, O. A. (2021). Translating Animal Idioms from English into Arabic: An Application of Nida's Strategies for Translating Idioms. Arab World English Journal for Translation \& Literary Studies 5 (3) 82-100.

DOI: http://dx.doi.org/10.24093/awejtls/vol5no3.7 


\section{Introduction}

A culture is like an iceberg; the tip of the iceberg is the language we speak, and the rest of the iceberg is the culture hidden under-surface. Each culture has its unique features that distinguish it from other cultures. However, people around the world share some of the same experiences resulting in similarities shared by different cultures. These similarities can result in shared idioms, connotative expressions, and proverbs. Yet, the unique features of each culture can exceed these similarities. Such features create an obstacle in the process of translation since the translator is considered a mediator, not only between two different language systems but also between two different cultures. When discussing the problems of correspondence in translation, "differences between cultures may cause more severe complications for the translator than do differences in language structure" (Nida, 1964, p. 130). The problem is even more when dealing with culturalspecific terms and expressions such as animal idioms.

People around the world use animals to describe certain characteristics. These characteristics can be positive or negative. Animal idioms may differ from one culture to the other based on how that culture perceives them. This study aims at studying animal idioms between Arabic and English, showing how they can be problematic in translation from English into Arabic, and presenting strategies that can be used to translate them.

\section{Significance of the Study}

Animal idioms are part of the cultural heritage used to express a certain idea. Therefore, the translation of animal idioms can be a daunting task for translators. If lost in translation or not translated accurately, animal idioms can cause a loss of meaning or misunderstanding. To avoid such complications, it is important to understand animal idioms in their own culture and then transfer them properly to the target culture.

\section{Statement of the Problem}

Translating idioms is not regarded as an easy task. Idioms carry a meaning that cannot be guessed from the meaning of the constituting parts. The problem is magnified when an idiom contains an animal that has a specific connotation within the culture it evolves in. Translators do not only transfer a segment from one language into the other; however, they are in a way cultural mediators who make sure that the message is clearly understood by the target audience. In the case of translating animal idioms, the difficulty relies on the fact that translators need to take into consideration three aspects. First, they should understand the connotation of the animal within the culture of the source language (SL). Second, they should realize the idea being expressed by the use of an animal idiom. Third, they should know how to translate the animal idiom into the target language (TL) properly.

Objective of the Study

Questions of the Study

The study aims at answering the following questions:

1. What are the strategies used by translators in translating animal idioms from English into Arabic according to Nida's strategies of translating idioms? 
2. What are the most common problems translators faced according to Nida's problems of translating idioms?

This study sheds light on problems encountered in translating animal idioms from English into Arabic. Furthermore, it presents strategies that can be applied in translating animal idioms according to Eugene Nida's proposed strategies for translating idioms. It also aims at identifying the most common problems encountered by the translators.

\section{Literature Review}

Common Linguistic and Textual Features of Idioms

Idioms have been defined by Al-Kadi (2015) as being untranslatable as their meaning cannot be predicted from its meaning especially if that idiom holds a social, historical or political background or connotation. According to Alhaysony (2017), Idioms can cause both linguistic and cultural problems, which could result in loss of communication of the intended meaning. For Moon (1998), there are three criteria shared by idioms. First, idioms are institutionalized where an expression becomes recognized in the language community. Second, idioms are lexicogrammatical fixed that refuse changes in their parts. Third, and most importantly, idioms are noncompositional, where the meaning of an idiom cannot be deduced from the meaning of its components.

Idioms also resist grammatical modifications. The words of an idiom cannot be re-ordered or substituted nor can new words be inserted. For Cruse (1986), idioms are internally cohesive just as single words even though they consist of more than one word.

\section{Problems of Translating Idioms}

Understanding a language is more than learning the meaning of its morphemes, lexemes, and compounds. In addition to these, it is about knowing the meaning of its fixed expressions such as idioms. Linguists agree on what an idiom stands for; however, they have different views on the difficulties imposed by idioms in the process of translation.

Ali\&Al-Rushaidi (2016) state that "it is not easy to find an equivalent in the target language that corresponds to the idiom in the source language both in meaning and in form" ( p.192). This is according to Optaria (2021) a result of the figurative language deeply embedded in idioms and why it cannot be translated literally, as it will seem ambiguous and meaningless.

For Baker (2011) the first challenge a translator faces, while translating an idiom, is the ability to recognize that $\mathrm{s} / \mathrm{he}$ is dealing with an idiom. Some idioms are not difficult to be identified such as it's raining cats and dogs while others are impossible to be recognised such as get your goat, which means to get angry. The second challenge involves problems faced in transferring different sides of the meaning that an idiom expresses into the TL. Baker (2011) provides an aid to guide translators to identify that they are dealing with an idiom. For her, the more complicated an expression seems to be and the more non-sense it makes in a certain context, the more likely it is to be an idiom. Hence, the pitfall for translators is the ability to decode idioms accurately. 
All languages have idioms, but it is not necessary to have an idiom in one language that corresponds to another idiom with the same meaning and form in another language. Newmark (1988) indicated that idioms are specifically difficult to translate because it is not easy to match the meaning of an idiom with its accurate equivalent in the TL. Balfaqeeh (2009) states that it is difficult to translate idioms because it is not always easy to find the equivalent for one lexeme "without finding equivalence for a sequence of words that convey one specific meaning" (p. 6). The Arabic language surpasses other languages with lexical richness. For example, with only one equivalent in English, the word lion, according to Alsayyoti (1998), has about 500 equivalents in Arabic including:

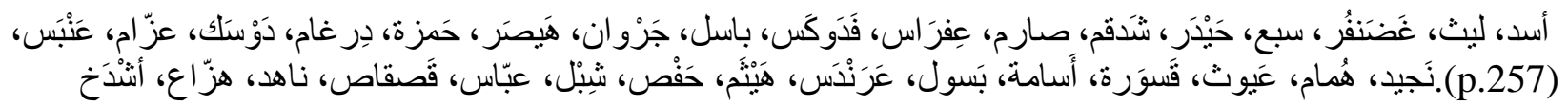

Idioms may contain a cultural-specific aspect that presents a challenge to translators. For Teilanyo (2007), idioms pose a challenge when they express a cultural-specific notion that is not easy to find an equivalent for in the TL as the two languages have different cultures and meaning subsystems. Abd Elmajid \& Ahmed (2016) agree and believe that untranslatability due to cultural and environmental differences is one of the main problems in translation. Classe (2000) points out that differences between the (source language)SL culture and the TL culture may result in loss of meaning in translation because some contextual aspects may express certain features that are exclusive to the SL culture and absent in the TL culture. For example, the Arabic idiom جنت على) (نفسها بر اقش), which is translated literally as "Barakesh caused it to itself", goes back to a dog named "Barakesh" owned by an Arab tribe. Barakesh used to bark when it felt an enemy was heading to its tribe. However, one day members of its tribe were hiding in valleys from a dangerous enemy but Barakesh kept barking which led the enemy to its tribe and caused the death of its people. To some point, an accurate translation of the idiom into English would be to dig one's own grave; yet, part of the meaning of the idiom will be lost. According to Emery (1997), the culturally-bound nature of idioms is what poses a challenge in their translation.

Nida (1964) differentiates between endocentric and exocentric expressions. Endocentric expressions are phrases of which the overall meaning can be deduced from the meaning of the constituents. On the other hand, exocentric expressions are phrases that cannot be understood from a semantic analysis of the constituting parts. Such expressions should be treated as single lexical units. Idioms are considered exocentric expressions of which the meaning applies to the whole expression and is not traceable to its parts. Nida refers to idioms as "figurative extensions of meaning" (Nida, 1964, p. 93). This is because the interpretation of figurative extensions does not depend on the literal meaning of words but extends to cover additional meaning components that are not found in the domain of such words.

For Nida (1964), translating exocentric expressions as if they were endocentric expressions is a problem that arises in the translation of idioms. A translator may not be aware that $\mathrm{s} / \mathrm{he}$ is dealing with an idiom and therefore tends to translate it literally. Thus, this would result in an inconsistent translation in the TL. For example, failing to identify that other fish to fry is an idiom 
which means "having more important things to do", a translator would give a literal translation that does not make sense in the receptor's language unless the exact idiom exists in both languages.

Another problem of translating figurative words, such as animal images in animal idioms, lies in having some features that are known by the people of a certain society as being dominant. Some animals are built upon certain dominant features in American English, such as "wolf (prowling rapaciousness), fox (sneakiness, cleverness)" (Nida, 1964, p. 94). These same animals may be known for other characteristics in other languages and cultures. Therefore, if a translator is unfamiliar with the connotation of the animal in the target culture, his/her translation may not yield the desired meaning. It can even result in an inappropriate one. For example, $a$ horse has a positive meaning in Arab culture and is known for its pride, grace, beauty, nobility, strength, and freedom. However, among the characteristics of a horse in western culture is having a large appetite. Therefore, the English idiom to eat like a horse will cause communication barriers if translated literally into Arabic as Arabs would associate a large appetite to a cow (i.e., to eat like a cow) and not a horse.

Also, exact extensions are not necessary to be found in all societies. In America, antelope is not employed in animal idioms and metaphors, but the same animal is vastly used in African idioms (Nida, 1964). Antelope is also found in Arabic idioms such as "ترك الظبي ظله", which is translated literally as "the antelope left its shadow", referring to a hateful person. In addition, the same term can exist in different cultures with distinct idiomatic significance. Nida mentions the example of coon, which is a shortened form of raccoon. The term is used in American English as a contemptuous figurative name to describe Negroes, associated with additional figurative extensions. On the other hand, a raccoon is employed in some American Indian languages to refer to "culturally cleverness" (Nida, 1964, p. 94).

In addition, one of the main problems of translating idioms, according to Nida (1964) lies in the style of idioms. Figurative expressions have different styles with respect to the cultures they evolve from. In English, most animal idioms refer to psychological characteristics, such as to get someone's goat which refers to making someone annoyed or angry. Similarly, in Arabic, many animal idioms refer to psychological characteristics and attitudes. For example, "كن مع الناس يمامة", which is translated literally as "be a dove with people", is used as a piece of advice as to be gentle. In Zuni, which is a Native American tribe, on the other hand, animal metaphors and idioms are mostly used to describe physical characteristics. For example, a person's hands are described as being rough like the feet of a turkey, someone's eyes can protrude like a rat's, and an individual may have bony legs like a bird (Newman, 1954).

Moreover, translating idioms are problematic because languages can be dissimilar in the extent to which they use idiomatic expressions and terms. In English, there are several idioms based on animals such as fox, geese, cow, rat, and others. Yet, the number of animal idioms in English is nothing compared to the number of animal idioms in Brazilian Portuguese, in which almost all animals have particular figurative extensions of meaning. Many of these animal idiomatic expressions have vulgar connotations. 
Furthermore, a problem in translating idioms can arise from differences in hierarchical status between words of the sender and receptor languages The SL idiom may contain an animal word of a lower rank, a higher rank, or the same rank but changed in position. The translator is sometimes forced to choose a term of a lower rank because there is no high-level equivalent in the receptor language.

Finally, languages are different in their readiness to accept new figurative expressions. For example, Tarascan, which is a language spoken in Mexico, does not have the readiness to accept new metaphors or idioms. On the other hand, Cuna, which is a language spoken in Panama, readily accepts new metaphors and idioms. Not only this, new metaphors and idioms are admitted in Cuna with significant cultural approval and sometimes even with eagerness (Nida, 1964).

Nida's Strategies of Translating Idioms

For Nida (1964), the first step a translator takes in the translation of idioms is to know that $\mathrm{s} / \mathrm{he}$ is dealing with one. There are some clues that languages usually provide to help a person differentiate between endocentric and exocentric expressions. Exocentric expressions may be introduced clearly by "as" or "like" (i.e., simile-like structures). Also, the style of exocentric expressions tends to be more poetic than endocentric ones which tend to use prose. After recognizing an idiom, Nida (1964) suggests some strategies that can be followed in translating it.

An idiom can be translated into another idiom. Idioms are related to the actual experience of a certain culture. Since people share some of the same experiences, the same idiom may exist in the SL and the TL. For example, the idiom shed crocodile tears, which refers to an insincere act of being sad (Piirainen, 2005), can be translated literally since the exact idiom is found in Arabic with the same meaning (يذرف دموع التماسيح). Besides, the same meaning may be expressed in the use of another idiom that is specific to the TL culture. For example, the idiom till the cows come home, which means "for a very long time or forever" is not found in Arabic. However, it can be rendered using another animal idiom expressing the same idea such as (حتى يرجع غراب نوح), translated literally as "until Noah's crow comes back". As Arabic is rich with its vocabulary, the same animal idiom in English may have multiple corresponding idioms in Arabic. For example, the idiom pigs might fly indicates things that will never happen. It can be translated into the Quranic

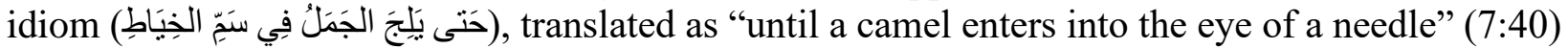
(Saheeh International., 2010). It can also be translated into one of the following Arabic idioms:

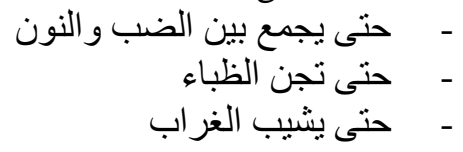

An idiom can be translated into a simile. Nida (1964) believes that the most effective way of translating an idiom is to render it as a simile if no corresponding idiom is found in the TL. Words such as "like" and "as" give a direct hint to the reader that the following phrase should be treated in a special way. For Nida (1964, p.219), "one does not say that some of the persons "bear fruit thirtyfold', but 'some are like seeds that increase to thirty". If this shift is not made, the translation into a culture where such idiom is unfamiliar can be confusing.

Arab World English Journal for Translation \& Literary Studies 
When a particular extension of meaning expressed by an idiom in the SL has no parallel in the TL, the idiom should be translated into a non-idiom. Idioms sometimes express a feature that is specific to the source culture and has no correspondence in the target culture. Therefore, a translator must make some radical alteration, often from a metaphor to a non-metaphor (Nida, 1964). For example, the idiom $\operatorname{dog}$ and pony show refers to a presentation intended to be influential, impressive, and supportive of a business proposal, product, policy, or candidate (Webster's New World Dictionary, 2015). In translating the idiom into Arabic, the idiom must be radically adjusted. It may simply be translated into a non- idiom such as "عرض ترويجي".

Some people reject Nida's strategies of translating an idiom into another idiom, an idiom into a simile, or an idiom into a non-idiom, as they believe that any shift involves some loss of information. On the other hand, the same people often do not mind a non-idiom being translated as an idiom because they consider it a way of increasing effective communication. Explaining this, Nida (1964, p.220) believes that "most people do not object to a profit in making a transfer from one language to another, but they do feel that a loss is reprehensible".

\section{Methodology}

Sample of the Study

The non-probability sampling frame consisted of 15 Saudi professional translators, who worked as full-time translation practitioners for a period not less than one year. Fourteen of these translators were aged between 25-34 and only one aged between 18-24. As for their certificates, 6 translators hold a bachelor's degree and 9 hold a master's degree.

Research procedures

The study adopted a combination of quantitative and qualitative approaches to analyze received respondents' answers. Using a combination of the two approaches provides the reader with a chance to explore data qualitatively and follow it with a more focused quantitative analysis.

\section{Data Analysis and Discussion}

This section provides a detailed quantitative and qualitative analysis of questionnaire participants' answers to the translation task. First, it discusses the strategies used by participants in rendering eight animal idioms from English into Arabic. Responses are classified into adaptation, literal translation, mistranslation, and omission. Then responses that opted for adaptation are further classified based on the three strategies of adaptation suggested by Nida (1964) in transferring idioms from the SL into the TL. After that, problems faced by translators are pointed out from Nida's point of view. At the end of each idiom, the researcher suggests a translation of the English idiom into Arabic. 


\section{An elephant in the room.}

\section{An elephant in the room}

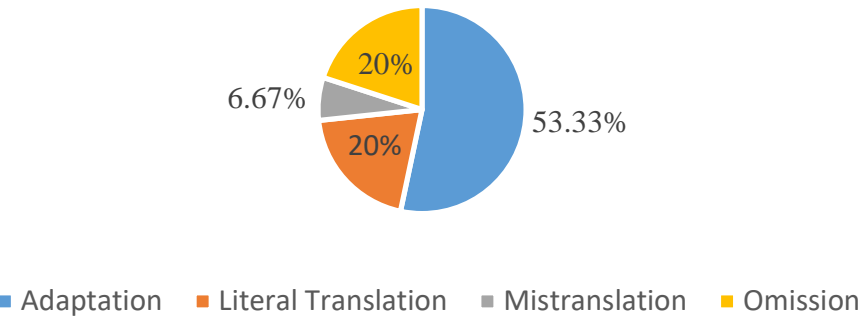

Figure 1.Animal Idiom 1

Meaning. An apparent truth or problem purposefully ignored by all parties in a certain situation (Sinclair, 1993).

At first glance, the idiom seems to have a literal meaning. Yet, considering the size of an elephant, it would be unrealistic to have it inside a room. An elephant is known for its big size regardless of the different perspectives that Arabs and westerns have, which would provide a hint somehow to the meaning of the idiom. The idiom was accurately adapted by (8 out of 15) of respondents. It was literally translated into هناك فيل في الغرفة/ يوجد فيل في الغرفة by (3 out of 15) and mistranslated into هناك غريب بيناك b" by (1 out of 15) of questionnaire respondents. A total of (3 out of 15) of respondents did not provide an answer to the meaning of the idiom.

As for adaptation strategies, only (1 out of 15) used an idiom of similar meaning in Arabic,

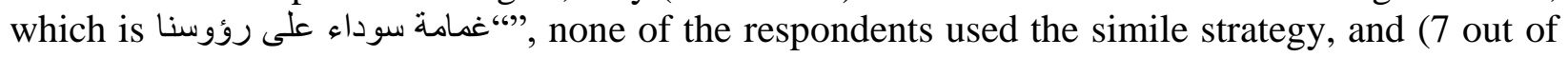
15) of respondents chose to translate it into a non-idiom. Translations that rendered the idiom into a non-idiom included the following:

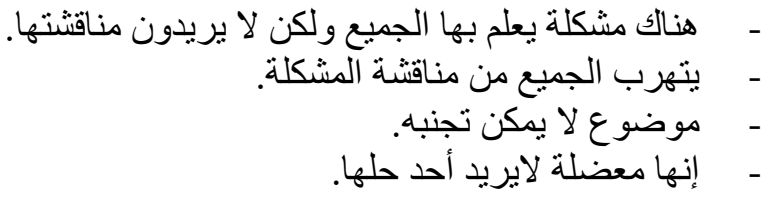

Respondents who could not provide an adaptation of the idiom constituted (7 out of 15). One of the reasons was translating the idiom literally. According to Nida (1964), this problem arises because translators treat endocentric expressions as if they were endocentric ones. Another reason was the unfamiliarity with the meaning of the idiom, which led to an interpretation that deviated from the original meaning. In addition, not making any attempt to translate the idiom was a third problem that prevented the transmission of the message from the SL into the TL.

Suggested translation. الثمس لا تُغطى بغربال - مثل عين الثمس 


\section{Every dog has its day.}

\section{Every dog has its day}

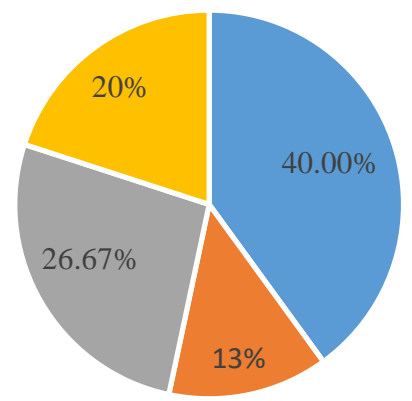

- Adaptation - Literal Translation $=$ Mistranslation $\quad$ Omission

Figure 2. Animal Idiom 2

Meaning. Every person will be lucky or find success one day (Siefring, 2005).

Arabs and westerns have different views when it comes to certain characteristics of dogs although they have some idiomatic expressions that show similar views concerning this animal as in better to be a live dog than a dead lion, which is similar to كلب جوال خير من أسد رابض Arabic. In Arab فلان أحرص من (Altha'alibi, 1965). On the other hand, dogs are valued and considered lovely pets in western culture, especially in the UK and the US (MacLachlan, 2017), and can be found to indicate positive connotations in idioms such as love me, love my dog and like a dog with two tails. Therefore, rendering the idiom from English into Arabic requires a cultural understanding of the SL and TL. Participants who rendered the idiom using adaptation constituted (6 out of 15); whereas participants who mistranslated the idiom accounted for (5 out of 15). Responses that mistranslated the idiom included:

$$
\text { - }
$$

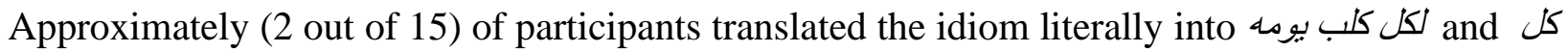
كلب بيتنتع بيومه and (2 out of 15) of participants did not provide any translation of the idiom.

Strategies used by participants in adaptation were translating the idiom into an idiom and إن مع العسر يبرًا which reflects the meaning of the idiom. Approximately (5 out of 15) of participants resorted to the non-idiom strategy to reflect the meaning. The translations included:

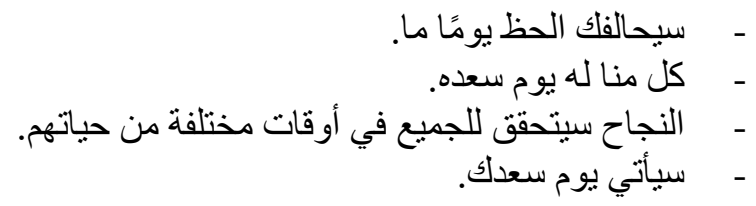

Arab World English Journal for Translation \& Literary Studies 
Respondents obtained low scores in the translation of this idiom as (9 out of 15) failed to provide an adequate translation. Trying to explain this, Nida (1964) believes that the problem lies in having certain features as being dominant in a particular culture when it comes to some animals. Another problem, according to Nida (1964), is that the same term may have different idiomatic significance in different cultures. In general, a dog has a negative connotation in Arab culture,

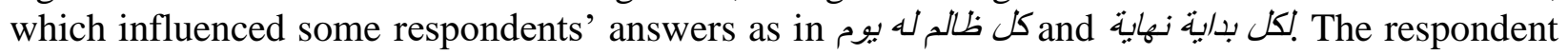

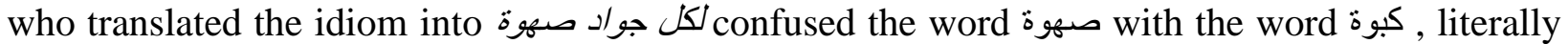
translated as "every horse stumbles". This shows that the unfamiliarity with idioms is not specific to English as the respondent showed that even Arabic idioms can be recalled incorrectly. It may indicate that failing to understand the meaning of an idiom would lead translators to resort to literal translation.

Suggested translation. لكل مجتهد نصيب- إن مع العسر يسرًا ما بعد الضيق إلا الفرج

\section{A snake in the grass.}

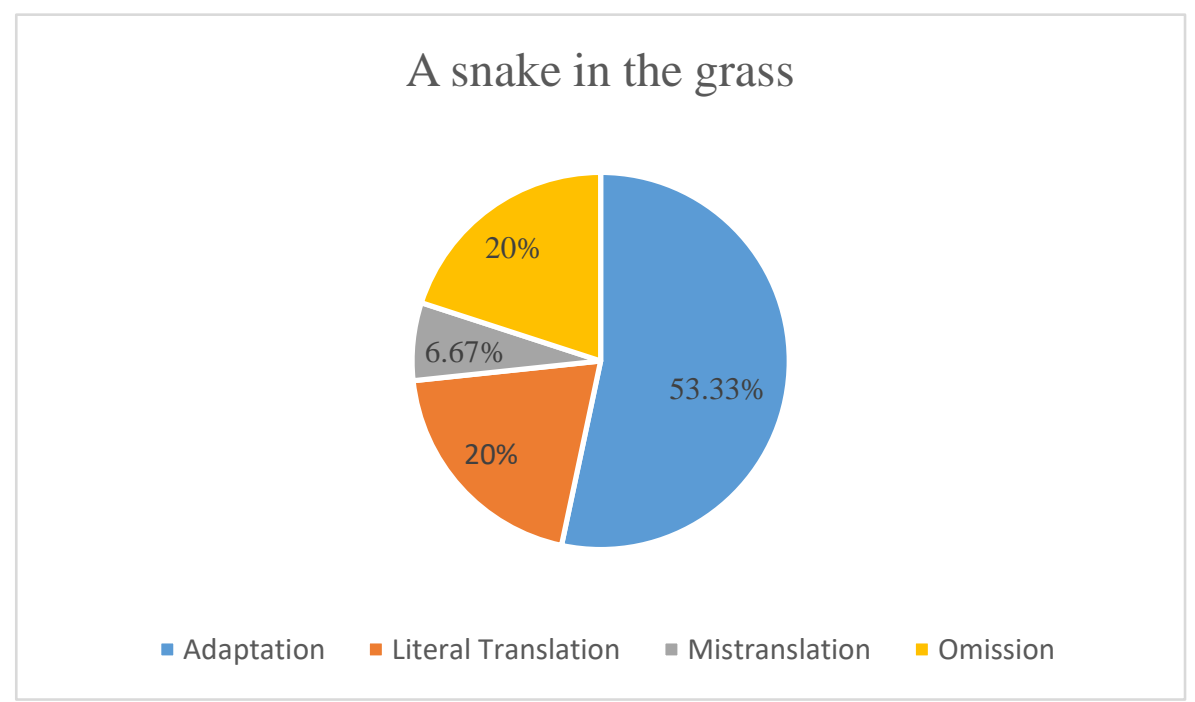

Figure 3. Animal Idiom 3

Meaning. A disliked person because of pretending to be a friend when s/he is actually an enemy who betrays people (Sinclair, 1993).

According to the Oxford Dictionary of Idioms, this idiom replaced the earlier idiom pad in the straw in the late $17^{\text {th }}$ century. Pad is an animal that was thought to be poisonous in the past (Siefring, 2005). In Arabic, a combination of the older English idiom and the newer version exists to reflect the same meaning, which is حبة من تحت تبن, translated literally as "a snake under the straw". Accurate responses were expected to be high since a comparable idiom is found in Arabic. However, only (6 out of 15) of respondents used adaptation techniques. A total of (4 out of 15) of respondents mistranslated the idiom, ( 2 out of 15) translated it literally, and ( 3 out of 15) of respondents left the item blank. Respondents' Arabic renditions involving the incorrect meaning of the idiom were:

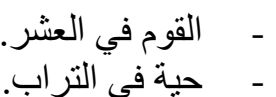

Arab World English Journal for Translation \& Literary Studies 


$$
\text { - }
$$

Respondents used the three strategies proposed by Nida (1964) in the translation of this idiom. Approximately ( 2 out of 15 ) of respondents translated the idiom into an equivalent idiom as بص يصطاد في الداء العكر and for the other strategies, (1 out of 15) rendered it into a simile a and (3 out of 15) of respondents translated it into a non-idiom:

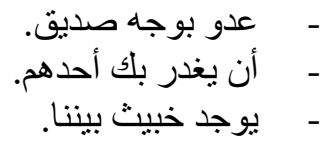

Only the first translation is considered an exact paraphrasing of the meaning of the idiom. Yet, the other two are considered somehow accurate since both respondents used words that reflect a deceiving person (i.e., يغدر) خيبث although the overall translation included unjustified additions.

A total of (9 out of 15) of respondents failed to provide proper meanings of the English idiom. Such erroneous translations can be attributed to respondents' lack of knowledge in English هناك أفعى في العشب idiomatic expressions in general, resulting in a literal translation of the idiom into or not providing any translation of the idiom. Literal translation of idioms is one of the problems highlighted by Nida (1964) in translating idioms. Translators sometimes treat exocentric expressions as endocentric ones, which results in an inconsistent translation. As for the response , حبة في التراب which is translated literally as "a snake in the sand", it was considered a mistranslation because the idea behind the idiom is that a treacherous person does not show it as a snake hides in the grass or straw; however, "a snake in the sand" will be obvious to everyone who sees it. Another challenge can be due to respondents' lack of awareness of the similarities between both cultures in the existence of some similar idiomatic expressions.

\section{Hold your horses.}

حية من تحت تبن- ذئب في جلد حمل Suggested translation.

\section{Hold yor horses}

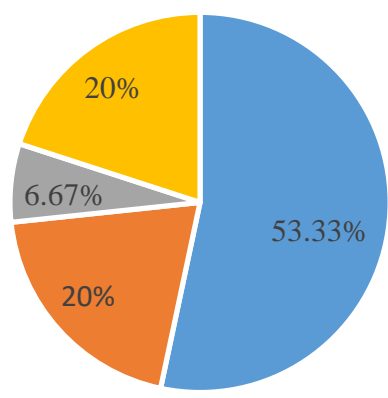

- Adaptation = Literal Translation $=$ Mistranslation $=$ Omission

Figure 4. Animal Idiom 4

Meaning. Control your enthusiasm or wait a little bit (Siefring, 2005). 
This idiom was adapted by ( 10 out of 15$)$, literally translated by ( 1 out of 15$)$, mistranslated by ( 2 out of 15), and omitted by ( 2 out of 15 ) of respondents. Most respondents showed an appropriate understanding of the meaning of the idiom and reflected it in the Arabic translation. The literal translation 1 / مسك / حصiنlmakes no sense in Arabic since an exact equivalence does not exist in Arab culture. Mistranslations may indicate that respondents could have tried to guess the meaning of the idiom, without being familiar with it, but failed to succeed, as the result was inaccurate rendition into ترقبوا and مسك زمام الأمور

Adaptation showed that (9 out of 15) of respondents opted for Nida's strategy (1964) of adapting an idiom into a non-idiom. Only (1 out of 15) of all respondents preferred to use Nida's idiom into an idiom strategy and translated it into كبح جماحك. Examples of respondents' translations into a non-idiom included:

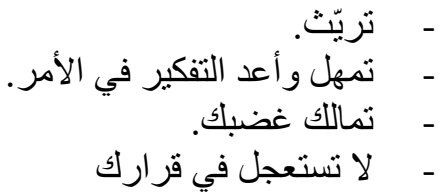

Problems that (5 out of 15) of respondents faced in the translation of this idiom can be due to the lack of unawareness of the strategies of translating idioms or unfamiliarity with the meaning of the idiom. The literal translation can be due to respondents' lack of awareness of the strategies used in the translation of idioms. Again, the problem of treating idioms as non-idioms and translating them literally appeared in the translation of this idiom as well. On the other hand, mistranslations, and omissions without making any effort to translate the idiom can be the result of respondents' unfamiliarity with the meaning expressed by the idiom in the source culture.

اكبح جماحك:Suggested translation

\section{One-trick pony.}

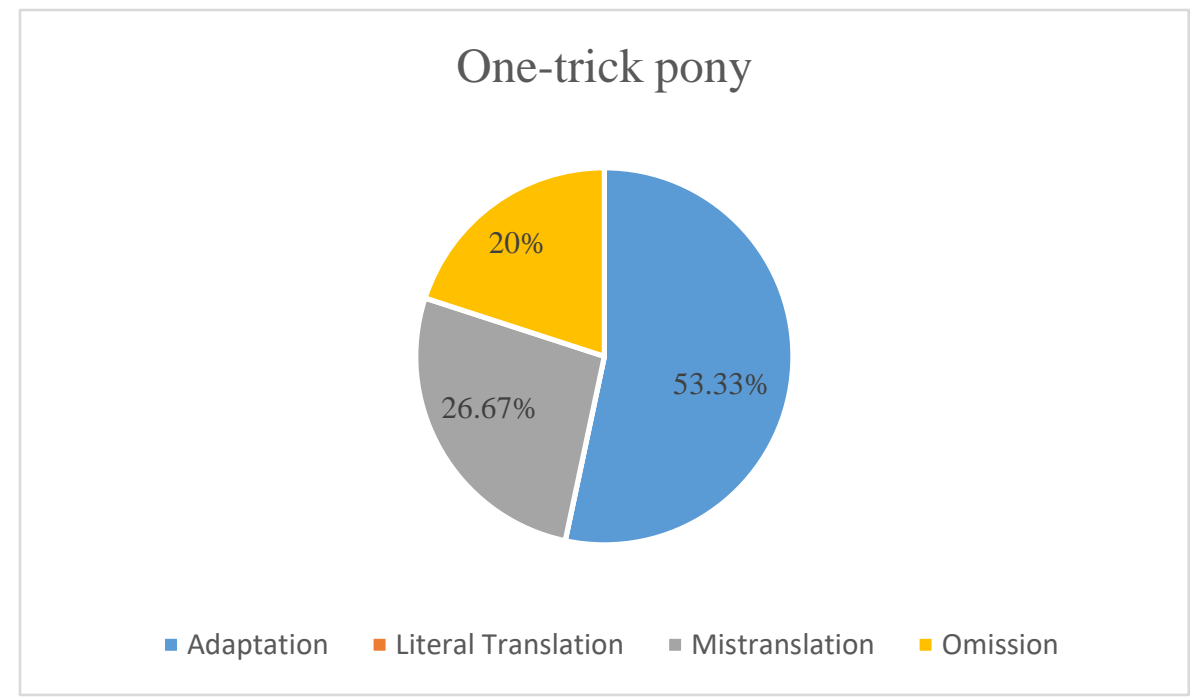

Figure 5. Animal Idiom 5 1993).

Meaning. A person or thing that has only one talent, quality, ability and so on (Sinclair, 
The idiom originated in the $19^{\text {th }}$ century. It goes back to circuses where ponies were taught to perform certain tricks (Aubakirova \& Gabdullina, 2017). An equivalent structure of the idiom is not found in Arabic. Therefore, it was the only idiom that none of the respondents provided a literal translation for. A total of (8 out of 15) of respondents understood the meaning of the idiom and chose adaptation. Yet, approximately (3 out of 15) of respondents did not make any attempt to translate the idiom and (4 out of 15) of respondents mistranslated the idiom into:

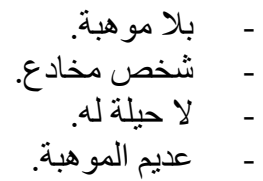

Although two of the questionnaire respondents who mistranslated the idiom understood that it can be related to talents, both eliminated the whole characteristic from the person or thing it refers to. Thus, both responses were considered a type of mistranslation since the meaning of the idiom has been lost.

For the adaptation strategies, a total of ( 8 out of 15) of respondents resorted to translating the idiom into a non-idiom. Responses for adaptation came out as:

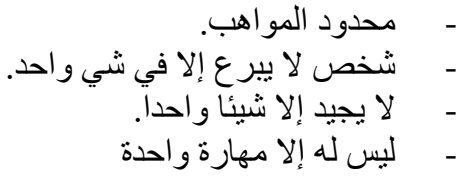

A total of (7 out of 15) of respondents did not provide an accurate translation of the idiom. From the problems suggested by Nida (1964) in the translation of idioms, it can be seen that the challenge respondents faced in translating this idiom can be because that exact extension is not found in Arabic. Although ponies are employed in Arabic idioms such as أتعب من رائض مر ", literally translated as "more difficult than training a pony", the association between ponies and circuses is not found in Arab culture. Also, the style of the idiom does not exist in Arabic which is another problem presented by Nida (1964). Different cultures have different styles of idioms that are not necessary to be shared with other cultures. Arabic and English belong to different language families. Arabic is one of the Semitic languages whereas English is one of the Germanic languages (Javed, 2013). Hence, they both have numerous differences not only in the culture but also in the language structure and style of idioms.

Suggested translation. ذو ميزة/ مهارة واحدة

A bull in a china shop.

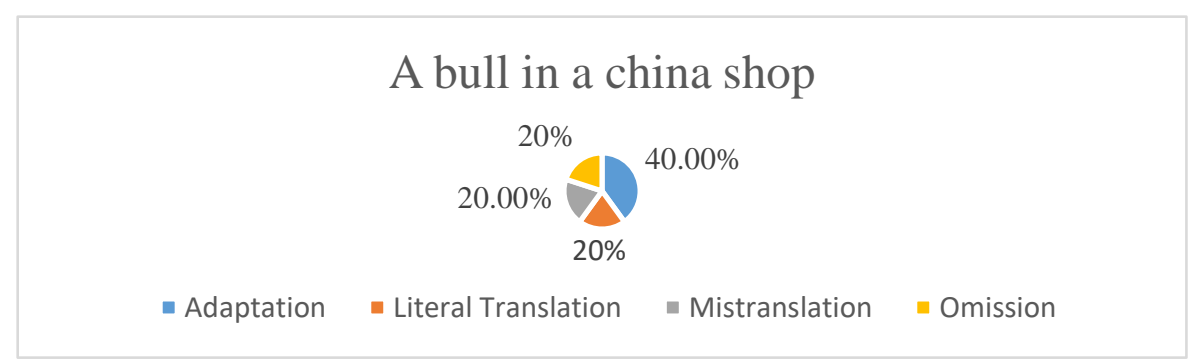

Figure 6.. Animal Idiom 6

Meaning. Acting recklessly in a situation where one may cause damage (Siefring, 2005).

Items in a china shop are fragile and breakable, so a bull is likely to crash things and create chaos if found in one of these shops. A comparable idiom is found in German where an elephant substitutes the bull to express the same idea in the idiom an elephant in a china shop. In Arabic, there is no exact equivalence of the idiom. Yet, the mental image of carelessness helps in 
understanding how the idiom is used. Roughly, (6 out of 15) of participants rendered the idiom using adaptation. A total of (3 out of 15) of participants translated it literally although one of the respondents began the translation with the simile strategy by using the word stich means "like"; yet, she completed the translation literally as مثل ثور في محل صيني, which made it unclear in Arabic. Approximately ( 3 out of 15) of participants omitted the idiom and ( 3 out of 15 ) of them mistranslated it into:

$$
\text { ـ ـ ـ كريب. من طين و أذخطن من عجين. }
$$

Strategies used in adaptation included translating the idiom into a non-idiom and into a simile. Only (1 out of 15) of participants used a combination of the non-idiom strategy followed by the simile strategy and translated the idiom into حركاته خرقاء كالثور الدنفلت في محل زجاج which clearly expressed the meaning of the idiom. A total of (5 out of 15) of participants opted for adapting the idiom into a non-idiom strategy. According to Collins COBUILD Dictionary of Idioms (Sinclair, 2006), the idiom is used to refer to a clumsy person. Therefore, translating the idiom into خرق

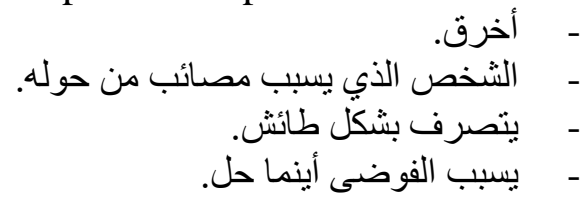

For the translation of this idiom, it is evident that (9 out of 15) of participants did not transfer the idiom from the SL into the TL in an accurate manner. Respondents scored low percentages in the translation of this idiom. One of the problems was translating the exocentric expression literally (Nida, 1964). Although the same idiom is not found in Arabic, some strategies can be used to render the meaning in the TL. Therefore, another challenge that many respondents encountered in translating the idiom was the unfamiliarity with the strategies used in the translation of idioms. A third problem can be attributed to the lack of knowledge in the SL, which made some participants leave the idiom without translation.

Suggested translation. منل الثور الهائج

Keep the wolf from the door.

\section{Keep the wolf from the door}

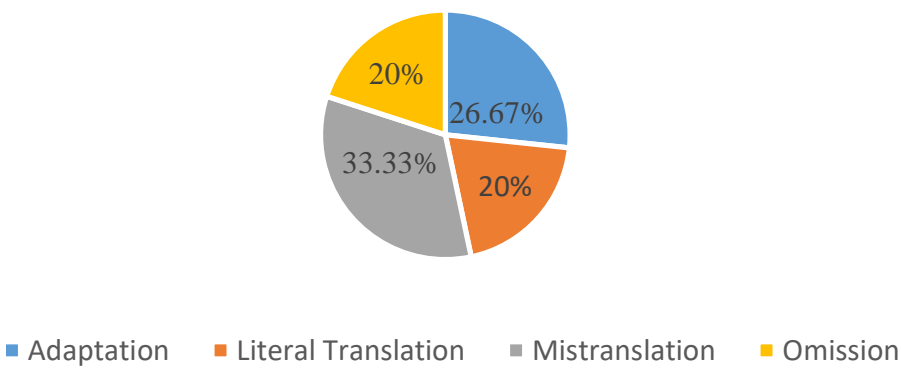

Figure 7. Animal Idiom 7

Meaning. Succeeding in providing food and necessary things for oneself and family (Sinclair, 1993). 
According to Flavell \& Flavell (2001), the wolf in this idiom symbolises "hunger". They further clarify that "since ancient times, the wolf has been a symbol of poverty and want" (p. 204). Fables usually depict wolves as being hungry and searching for food. Therefore, stopping a person from reaching one's door means keeping starvation from his/her house. When asked to translate the idiom into Arabic, (4 out of 15) of respondents used adaptation. Whereas, (3 out of 15) of

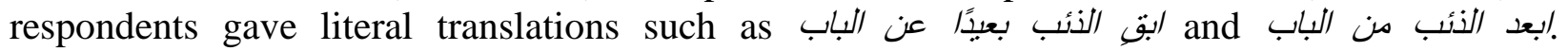
Approximately ( 3 out of 15 ) omitted the idiom and (5 out of 15) of respondents mistranslated it into:

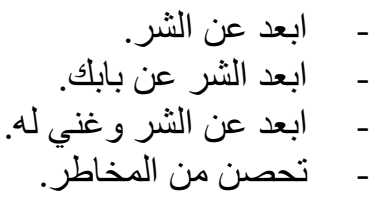

For adaptation, all (4 out of 15) of respondents adopted the strategy of translating the idiom into a non-idiom. Even though a low percentage of respondents provided adequate renditions, translations that adapted the idiom into a non-idiom expressed the meaning of maintaining oneself at a level sufficient only to provide things needed to live. Such adaptations included:

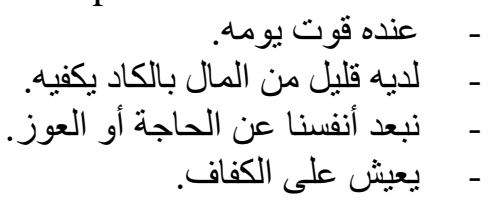

The finding clearly indicates that this item scored the highest percentages in omissions and inaccurate translations of the idiom. A total of (11 out of 15) of the questionnaire respondents failed to render the idiom accurately into Arabic. According to Nida (1964), a problem that translators face in rendering cultural-specific expressions lies in having certain prevailing characteristics known by some societies. The symbolization of a wolf as being dangerous, treacherous and greedy are recurrent in figurative language and supported by various cultural codes (Dobrovol"skij \& Piirainen, 2005). In general, although a wolf is used sometimes in Arab culture as a complement of being brave, it often denotes danger and this specific characteristic prevailed in respondents' inaccurate translations. Another problem was the lack of respondents' knowledge of the other characteristics associated with a wolf in western culture. Furthermore, translating the idiom as an endocentric expression was a third problem that respondents encountered although all of them are translators who have not less than one year of experience in translation.

$$
\begin{aligned}
& \text { Suggested translation. لكي لا نشكو قلة الفئر ان/الجرذان في بيتناـ الحصول على البُلغة من العيش- توفير ما }
\end{aligned}
$$

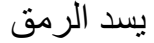




\section{Monkey see, monkey do .}

Monkey see, monkey do

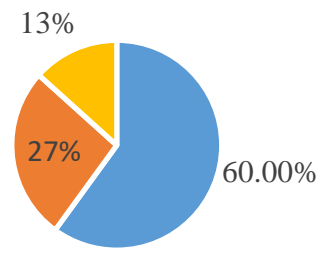

- Adaptation - Literal Translation $\quad$ Mistranslation $\quad$ Omission

Figure 8. Animal Idiom 8 1993).

Meaning. Copying the behaviour of others without a sense or understanding (Sinclair,

The link between the literal and figurative meaning of this idiom is established by semiotic knowledge about the animal in question and its meaning in the culture that uses it (Ding, 2018). In this idiom, "monkey" assumes the symbolic function of imitation. In responding to the idiom, none of the respondents mistranslated the idiom. A total of (9 out of 15) of respondents succeeded in the adaptation of the idiom. While, (4 out of 15) of respondents provided literal renditions that included القرود ترى وتفعل and القرد برى وبيفل تقرد برى وقرد بفعل Approximately (2 out of 15) of respondents left the idiom blank.

Respondents chose the strategies of translating the idiom into an idiom and translating it into a non-idiom in adaptation. Only (1 out of 15) of respondents used the idiom to an idiom strategy and succeeded in translating it into مع الخيل يا شقراء which is an Arabic animal idiom, widely used in Saudi Arabia, that means imitation without thinking. Approximately, (8 out of 15) of التقلي الأعدى (5. Thespondents transferred the idiom into a non-idiom. Their translations ranged between and يقّلّ .

The finding explicitly reveals that the main problem respondents showed in the translation of this idiom is rendering it literally. According to Nida (1964), when exocentric expressions are translated as if they were endocentric ones, the result will be an inconsistent translation. The literal translations do not convey the desired meaning nor are they intelligible to Arab readership. Achieving a successful translation of figurative expressions requires having a cultural background of the SL along with a metaphorical translational process. It also demands extra effort from the translator to adapt the target version to the cultural expectations of the target readership (Bekkai, 2009).

Suggested translation. - مع الخيل يا شقراء نزوَ الفرار استجهل الفرار - مثل البيغاء- 
AWEJ for Translation \& Literary Studies Volume, 5 Number 3. August 2021

Translating Animal Idioms from English into Arabic

Al-Qahtani \& Al Qahtani

Table 1

Overall Scores of Respondents' Translations of Given Animal Idioms

\begin{tabular}{|c|c|c|c|c|c|c|c|c|}
\hline \multirow[t]{2}{*}{ Idiom } & \multicolumn{2}{|c|}{$\begin{array}{l}\text { Adaptatio } \\
\text { n }\end{array}$} & \multicolumn{2}{|c|}{$\begin{array}{l}\text { Literal } \\
\text { Translation }\end{array}$} & \multicolumn{2}{|c|}{$\begin{array}{l}\text { Mistranslatio } \\
\text { n }\end{array}$} & \multicolumn{2}{|c|}{ Omission } \\
\hline & No & $\%$ & No. & $\%$ & No. & $\%$ & No. & $\%$ \\
\hline An elephant in the room & 8 & $\begin{array}{l}53.3 \\
3\end{array}$ & 3 & 20 & 1 & 6.67 & 3 & 20 \\
\hline Every dog has its day & 6 & 40 & 2 & 13.33 & 5 & 33.33 & 2 & 13.33 \\
\hline A snake in the grass & 6 & 40 & 2 & 13.33 & 4 & 26.67 & 3 & 20 \\
\hline Hold your horses & 10 & $\begin{array}{l}66.6 \\
7\end{array}$ & 1 & 6.67 & 2 & 13.33 & 2 & 13.33 \\
\hline One-trick pony & 8 & $\begin{array}{l}53.3 \\
3\end{array}$ & 0 & 0 & 4 & 26.67 & 3 & 20 \\
\hline A bull in a China shop & 6 & 40 & 3 & 20 & 3 & 20 & 3 & 20 \\
\hline $\begin{array}{l}\text { Keep the wolf from the } \\
\text { door }\end{array}$ & 4 & $\begin{array}{l}26.6 \\
7\end{array}$ & 3 & 20 & 5 & 33.33 & 3 & 20 \\
\hline Monkey see, monkey do & 9 & 60 & 4 & 26.67 & 0 & 0 & 2 & 13.33 \\
\hline Total & 57 & 30.4 & 18 & 9.6 & 24 & 13 & 21 & 11 \\
\hline
\end{tabular}

\section{Conclusion}

Summary of Findings

This research aimed at identifying problems and difficulties in translating animal idioms from English into Arabic by professional translators. The findings of the first research question showed that $30.4 \%$ of the respondents opted for the strategy of translating an idiom into a nonidiom. Respondents used this strategy to translate all the specified animal idioms but significantly more when the idiom has no correspondent in the TL. Yet, some of the translations were inaccurate because respondents did not grasp the actual meaning of the idiom. Translating an idiom into an idiom came in second place in the adaptation strategies used accurately by respondents. However, in some cases, respondents rendered given idioms into other idioms of dissimilar form and meaning in Arabic. Thus, such translations were considered inaccurate. The last and least used adaptation strategy was translating the idioms into similes. Respondents may not be aware of this strategy as an adequate one for the translation of idioms into the TL. Other strategies used by respondents which resulted in inaccurate translations included literal translation, mistranslation, and omission.

Regarding the findings of the second research question, the study stated the problems from the most to the least frequent problem based on Nida's (1964) proposed problems. The most frequent problem was not having enough experience and cultural background in the SL that is needed to infer the idioms adequately, which led to the misinterpretation of the meaning of idioms and thus generated inaccurate renditions. Following this problem was respondents' insufficient linguistic ability in the TL. Such difficulty prevented respondents from providing equivalent 
idiomatic expressions in the TL that reflect the same idea and kept them from manipulating the structures of the TL to produce idiomatic ones. The third problem was rendering these idioms as if they were non-idiomatic ones. In other words, translating these idioms literally is one of the reasons for inadequate translation. Idioms have meaning that is not related to the meaning of their words. Therefore, transferring them literally creates structures with no specific meaning to the target (Arab) readership. According to Nida (1964, p. 145), a translator must have an "excellent back-ground in the SL and at the same time must have control over the resources of the language he is translating into."

\section{About the Authors}

Filwah Al-Qahtani is a professional translator and she currently works as head of technical committee's department. She holds a bachelor's degree in translation from King Saud university and a master's degree in translation from Imam Mohammed Ibn Saud Islamic university. https://orcid.org/0000-0003-0164-8047

Osama Al Qahtani is an Assistant professor of Translation Studies. He holds a bachelor's and a master's degree in Arabic/English Translation and Interpreting from the United Kingdom. He also holds a PhD degree from the United Kingdom in Translation Studies. His research interests are mainly in the field of translation studies. He published several papers in different journals. https://orcid.org/0000-0001-5154-0419

\section{References}

Abd Elmajid, W., \& Ahmed, M. (2016). A Contrastive Analysis of English and Arabic Translation Problems. Journal of Human Sciences, 17(4), 2131-144.

Ali, H \& AL Rushaidi, S. (2016). Translating Idiomatic Expressions from English into Arabic: Difficulties and Strategies. Arab World English Journal, 7(4), 187-201. https://dx.doi.org/10.24093/awej/vol7no4.13.

Al-kadi, A. (2015). Towards Idiomatic Competence of Yemeni EFL Undergraduates. Journal of Language Teaching and Research, 6(3), 513-523. DOI: http://dx.doi.org/10.17507/jltr.0603.06

Altharalyby, A. (1965). Thimar alqulwb fy almudafi waalmanswub (The Genitive and Accusative) . Dar almararif, Cairo, Egypt.

Alsyuty, J. (1998). Almuzhir fy culum allu،ah,t wa anwariha (The science of language and its types). Dar alkutub al iilmiyah,t. Beirut, Lebanon.

Baker, M. (2011). In other words: A Coursebook on Translation. Journal of Women's Health.

Bekkai, M. (2009). The influence of culture on Arabic/English/Arabic translation of idioms and proverbs. Mentouri University-Constantime, Algeria.

Belfaqeeh, N. (2009). Strategies for translating idioms and culturally-bound expressions within the human development genre. University of Birmingham, United Kingdom.

Leighton, H. (2000). Heinrich Boll. In O. Classe (1). Encyclopedia of literary translation into English (pp.168-171).Taylor \& Francis.

Cruse, D. A. (1986). Lexical semantics. Cambridge university press.

Delisle, J., Lee-Jahnke, H., \& Cormier, M. C. (Eds.). (1999). Terminology of Translation (Vol. 1). John Benjamins Publishing. 
Dobrovol'skij, D. \& Piirainen, E. (2005). Figurative language. Cross-cultural and cross-linguistic perspectives. - Amsterdam: Elsevier.

Emery, P. (1997). Omani proverbs: problems in translation. R. Smith \& R. Smart \& R. Pridham, 4, 39-70.

Flavell, L., \& Flavell, R. (1994). Dictionary of idioms and their origins. Kyle Cathie Ltd.

Javed, F. (2013). Arabic and English phonetics: A comparative study. The Criterion: An International Journal in English, 4(4) 1-14.

MacLachlan, M. (2017). Perceptions of Animals across Cultures: Man's Best Friend or Dirty Beast. Retrieved from https://www.Perceptions of Animals across Cultures: Man's Best Friend or Dirty Beast? (communicaid.com).

Meryem, M. (2010). Problems of idioms in translation case study: First year master. Mentouri University: Constantine.

Moon, R. (1998). Fixed expressions and idioms in English: A corpus-based approach. Oxford University Press.

Newman, S. (1954). American Indian linguistics in the Southwest. American Anthropologist, 56(4), 626-634. American Indian Linguistics in the Southwest - NEWMAN - 1954 American Anthropologist - Wiley Online Library.

Newmark, P. (1988). A textbook of translation (Vol. 66). New York: Prentice Hall.

Nida, E. A. (1964). Toward a science of translating: with special reference to principles and procedures involved in Bible translating. Brill Archive.

Piirainen, E. (2005). Europeanism, internationalism or something else? Proposal for a crosslinguistic and cross-cultural research project on widespread idioms in Europe and beyond. HERMES-Journal of Language and Communication in Business,18(35), 45-75. https://doi.org/10.7146/hjlcb.v18i35.25816.

Saheeh International. (2010). The Qur'an. Riyadh: Al-Muntada Al-Islami Trust.

Teilanyo, D. (2007). Figurative language in translation: A study of JP Clark's The Ozidi Saga. Meta: journal des traducteurs/Meta: Translators' Journal, 52(2), 309-326. 